Note: This is a pre-publication final draft. For the published version, please see: Rafalow, Matthew H., Cynthia Feliciano, and Belinda Robnett. (2017). "Racialized femininity and masculinity in the preferences of online same-sex daters." Social Currents 4(4): 306-321.

\title{
Racialized Femininity and Masculinity in the Preferences of Online Same-Sex Daters.
}

Matthew H. Rafalow

University of California-Irvine

Cynthia Feliciano

University of California-Irvine

Belinda Robnett

University of California-Irvine

\begin{abstract}
This study considers how online dating preferences reflect gendered racial inequality among same-sex daters. Research shows that heterosexuals reproduce gendered racial hierarchies through partner preferences, yet little work examines the preferences of sexual minorities, especially lesbians. Moreover, few studies examine racial heterophily (a preference for racial groups other than one's own), which may influence interracial pairings. Using data from 4,266 Match.com dating profiles, we find that Asian, Latino, and Black lesbians and gays exhibit higher rates of racial heterophily than do Whites. Lesbians of color are less likely to self-exclude or to prefer Whites, and are more likely to not state a race preference than are minority gays. Self-exclusionary minority daters often discuss ideal masculinities and femininities in their profiles, suggesting that such exclusions are motivated by both racialized and gendered ideals for partners. Drawing on theories of homonormativity, we conclude that gays conform more to racialized, gendered ideals than do lesbians.
\end{abstract}

This paper focuses on patterns of racial heterophily - a preference for racial groups other than one's own - among lesbian and gay ${ }^{i}$ daters, a phenomenon obscured by most research on romantic inequality that examines the demographics of partner outcomes rather than the preferences $^{i i}$ that shape these outcomes. Scholars find that lesbians and gays are more likely to be in interracial unions than are heterosexuals (Rosenfeld and Kim 2005). Further, gays are more likely to interracially cohabitate or marry than are lesbians (Lin and Lundquist 2015; Schwartz and Graf 2009), but studies cannot explain this pattern, which may stem from opportunity constraints or differing racial preferences. Existing studies also do not consider the possibility that signs of increased openness mask patterns of racial self-exclusion. ${ }^{\text {iii }}$ Some minority daters may not be open to dating members of their own racial-ethnic group.

Varying racial heterophily patterns provide insight into how racial hierarchies differ by gender among same-sex daters, and may explain why gays are more likely to interracially couple 
than lesbians. For minorities, racial heterophily is theoretically important because it suggests internalized racial oppression (Pyke 2010a) via rejection of one's own group in favor of Whites. For example, Pyke (2010b) finds that second-generation heterosexual Asian women's exclusion of Asian men and preference for White romantic partners indicates internalization of negative Asian stereotypes and not just superiority of White masculinity. However, studies have not examined how racial self-exclusion varies for lesbians as compared with gays.

Literature on racial pairings among heterosexuals suggests homophily, or preferring one's own group, is the dominant pattern, even among minorities (Lin and Lundquist 2013). However, recent work finds differences in heterosexual daters' same-race preferences by race and gender (Lin and Lundquist 2013; Robnett and Feliciano 2011), and gender differences in homophily among White homosexual daters (Lundquist and Lin 2015). We extend these existing studies by examining gender and racial differences in homophily and heterophily among White, Asian, Black, and Latino same-sex daters on the online dating website, Match.com. In addition, unlike other studies, we analyze both quantitative data on stated racial preferences as well as qualitative data from daters' profile texts.

Examining dating preferences provides a window into how inequalities in union formation are created. Casual sexual encounters may not have implications for long-term mate selection, and while already-formed unions reveal inequalities in economic stability and other outcomes, they do not show the underlying mechanisms leading people to couple intraracially, interracially, or not at all. In contrast to psychological and structuralist explanations for same-sex dating patterns, which emphasize individual preferences or partner availability, we extend previous sociological work focusing on how mate selection is a by-product of other social forces (Kalmijn and Flap 2001). In this study, we argue that daters' racial preferences are a byproduct of the construction of social and cultural categories. Through a mixed-methods approach, we show that not only are Whites much more homophilous than minority same-sex daters are, and gay minority males more heterophilous than both White gays and minority lesbians, but that racial heterophily is tied to ideal racialized masculinities and femininities that privilege Whites. Thus, while demographic studies indicate that gays and lesbians often couple interracially and suggest that this is due to partner availability, we argue that underlying these patterns are gendered and racial ideals that gays conform to more than lesbians.

\section{Interracial Pairings among Same-sex Couples}

Recent studies of racial inequality paint a rosier interracial relationship picture for samesex daters than heterosexuals because lesbians and gays are more likely to interracially couple than are heterosexuals. Scholars suggest this is due to partner availability (Rosenfeld and Kim 2005; Schwartz and Graf 2009): lesbians and gays tend to live in diverse areas and participate in subcultures where greater racial mixing occurs (Chauncey 1994; Kennedy and Davis 1993). However, White gays and lesbians are least likely to interracially pair, followed by Blacks, Latinos, and Asians (Kastanis and Wilson 2014). Further, although both lesbians and gays are more likely to interracially couple than are heterosexuals, lesbians, especially White lesbians, are less likely to do so than gays (Schwartz and Graf 2009). It is unclear whether preferences or opportunities shape these patterns. In an effort to tease out these factors, Lundquist and Lin (2015) analyze White daters' messaging behaviors on an online site, finding that White lesbians initiate more cross-racial interaction than White gays do; they suggest that partner availability, rather than racial preferences, explains why gays are more likely to interracially couple than 
lesbians. However, another possibility, which we consider here, is that pairings are driven both by the preferences of Whites and minorities, and preferences for Whites by minority daters may be gendered.

\section{Gendered Racial Hierarchies in the Dating Market}

Theories of gendered racial hierarchies examine the ways in which gender intersects with race to determine one's position in the heterosexual dating market (Robnett and Feliciano 2011). Heterosexual Whites tend toward racial homophily (Lin and Lundquist 2013; Rosenfeld and Kim 2005). Homophilous preference among Whites is not necessarily a harmless pursuit of similar others, but rather a symptom of broader racial hierarchies where daters seek the highest status racial group (Kalmijn 1998). Thus, heterosexual Whites' persistent tendency to seek same-race dates maintains their dominant social position (Lin and Lundquist 2013).

However, gender variation by race complicates patterns of racial hierarchies. For example, heterosexual White men more often partner with or prefer Asian than Black women, and heterosexual White women more often partner with or prefer Black than Asian men (Jacobs and Labov 2002; Robnett and Feliciano 2011). To explain these differences, scholars argue that intersections of race, masculinity, and femininity shape ideals of desirability. For example, controlling images that permeate society depict Black women as masculine and Asian men as feminine; they thereby tend to be viewed as less desirable than Black men and Asian women who are seen as more masculine and feminine, respectively (Collins 2004; Feliciano, Robnett and Komaie 2009).

Intersectional research suggests that similar hierarchies and race-gender ideals of desirability exist among gay daters and lead to sexual racism within this community. Gays of color report marginalization in primarily White gay social environments (Stokes and Peterson 1998): Black men are often treated as hypermasculine sex objects and Asian men as effeminate undesirables (Wilson et al. 2009). Although research on these race- and gender-based assumptions about gays is primarily qualitative (Collins 2004; Wilson et al. 2009), some quantitative work finds that gays exhibit racial hierarchies in their preferences for dates (Phua and Kaufman 2003) and sex workers (Logan 2010). This work assumes that racialized notions of masculinity and femininity are monolithic and shared across gender, racial and sexual groups. However, Lin and Lundquist (2013) suggest that the stereotypical depictions of Blacks and Asians reflect Whites' tastes for minority groups and do not explain infrequent pairings between Blacks and Asians. This literature also offers little insight as to how lesbians may differ from gays in their relative commitments to these normative ideals.

\section{Homonormativity and Racial Self-Exclusion}

A missing element from theories of race- and gender- based hierarchies in dating is how power, expressed through hegemonic cultural ideals, may influence romantic preferences. We draw on theories of homonormativity to explain how daters' stated preferences for gender and race shape romantic inequality among same-sex daters.

Duggan (2002) defines homonormativity as the proliferation of culturally specific ways of being queer that are in enough 'sync' with existing gender, class, racial and cultural norms to be broadly acceptable. For example, Asencio (2011) finds that Puerto Rican gays marginalize feminine gays (locas) while privileging traditional forms of masculinity. Walker and Eller (2015) 
also find that gays on Match.com conform to heternormative masculine ideals. And in another pertinent case, Collins (2009) finds that White gay expatriates to the Philippines, through sexual pursuit of Filipino men, reify their own homonormative constructs as White ideals among "exotics." Homonormativity envisions intersections like race and gender as co-occurring, collectively produced features of desire with implications for inequality and thus can, for example, account for why a minority gay man might prefer White, masculine men and not minority and/or effeminate men. Similarly, Bourdieuian theories of power suggest that subconscious desires are collectively produced and drive social patterns (Bourdieu 2001; Schmitz 2012). In this view, homonormative commitments may be shared by groups, such as lesbians and/or gays, and expressed through their desires.

\section{Gender Differences in Same-Sex Coupling}

Like Collins (2009), we contend that homonormative forces may govern gays' practices in the form of sexual and romantic desire for those who inhabit ideal race and gender statuses. Lesbians, however, may differ from gays. One possibility is that lesbians may not prioritize preferences for sexual or physical ideal types as often as gay men when looking for a relationship (Baker 2005; Thorne and Coupland 1998). Some researchers argue that gays have greater economic resources and more to gain from respectable performances of gay masculinity, and thus homonormativity, than do lesbians (Collins 2009). Others suggest that penalties for nonconformity are particularly severe for gays (Asencio 2011; Connell 2005). Thus, gays may conform more to homonormativity than do lesbians.

Relatedly, Rich (1980) famously argued that lesbians occupy both a constrained and liberating social position. In this view, lesbianism can itself be seen as a rejection of, and also rendered invisible by, a broader system of homonormativity. It may be that lesbians have not internalized a homonormative habitus to the degree that gays have (Bourdieu 2001). Other work also finds that lesbians both inhabit and pursue more varied and transgressive forms of gender identities and performances than do gays (Farr 2011; Wilson 2009). Further, when lesbians of color inhabit ideal masculinities or femininities they do not always reap its rewards, such when masculine Black lesbians face discrimination on the street (Moore 2008) and feminine Black lesbians garner unwanted sexual attention from heterosexual men (Steinbugler 2005). Scholarly work on lesbian experiences, particularly among lesbians of color, suggest that homonormative ideals may be collectively less espoused by lesbians than gays.

\section{Data and Methods}

We use mixed methods, combining quantitative and qualitative analyses of data collected in March 2011 from Internet dating profiles posted on Match.com, the leading Internet dating website at the time, with estimates of up to 35 million unique visitors each month (eBiz 2015). We qualitatively analyze smaller samples to understand what drives the observed quantitative patterns.

We selected random, stratified samples of daters who self-identified as Black, White, Latino, or Asian living within 50 miles of Los Angeles, Chicago, Atlanta, and New York City. We chose one large city within each major region of the U.S. since historically, racial attitudes have varied widely by region (Firebaugh and Davis 1988), and so that we could consider cities with high concentrations of same-sex couples ${ }^{\text {iv }}$ and varied racial compositions. We randomly 
selected 200 profiles for each race/gender/sexuality/region combination. ${ }^{v}$ This paper focuses exclusively on same-sex daters who identify solely as White, Black, Asian or Latino $(\mathrm{n}=4,266){ }^{\mathrm{vi}}$

Internet dating has become a mainstream activity, and recent survey research finds that Internet daters are not largely different across demographic characteristics (including gender, race or education) from single Internet users who do not use Internet dating services (Sautter, Tippett and Morgan 2010). Moreover, Internet dating is increasingly common and indeed, the most common way gay and lesbian couples meet (Rosenfeld and Thomas 2012). Nevertheless, people who date on the Internet are not a random sample of people who date. Internet users themselves remain a select sample, and this is especially so among Blacks and Latinos (Martin and Robinson 2007).

Given the abundance of online dating websites, we were concerned about self-selecting minorities who are especially open to interracial dating. However, Match.com is used by a diverse set of daters. In separate analyses, we compared the racial composition of Match.com to Internet users in the Current Population Survey, and found that Whites are not overrepresented relative to this population within each metropolitan area (see Supplemental Table 1), and samesex daters are especially diverse. This suggests that Match.com is not primarily a website for those searching for Whites, especially among lesbians and gays.

In other analyses, we considered that the demographics of Match.com users may differ from the demographics of internet users in these metropolitan areas, and found few differences (see Supplemental Table 2). However, compared to Internet users, Match.com users are more educated. Thus, our findings cannot be generalized beyond the population of U.S. Internet users in four metropolitan areas, who have higher socioeconomic status than the general population. Further, Match.com appears to attract an even more educated (and likely higher-earning) clientele than other dating websites because one must pay to communicate with members. While this limits the generalizability in terms of dating patterns, Match.com is known as a dating website for more serious daters looking for long-term relationships. ${ }^{\text {vii }}$ We consider this a strength of this data as racial preferences found here can be considered mechanisms shaping the racialmakeup of same-sex couple households.

Selection issues also suggest that any biases in our results would be in the direction of underestimating the actual degree of racial homophily or heterophily since more educated respondents have been shown to express more socially desirable racial attitudes that are inclusive of everyone (Bobo and Massagli 2001). An underestimation overall, however, would not bias the particular patterns of responses we see in terms of racial homophily or heterophily. Another limitation is that Match.com does not provide users with categories for role/sex position preferences, which may be gendered and racialized, e.g., gay Black men primarily valued as dominant and/or insertive partners versus Asian gays primarily valued as submissive and/or receptive partners (Han 2006) or butch/tomboy/femme as a key part of pairing among lesbians (Farr 2011; Thorne and Copeland 1998; Smith and Stillman 2002). Although our study shows that these differences may be subsumed among larger patterns of desire structured by homonormative race and gender ideals, this dataset may miss important distinctions along these characteristics.

Another concern is that daters may not accurately convey their preferences. However, a study of online contact among Internet daters shows that individuals who state preferences are more likely to behave according to those preferences than those who choose the default profile options (Hitsch, Hortascu and Ariely 2010). Since others can view their stated preferences, any misconceptions of daters' preferences are more likely to exist among those who express that they 
have no racial dating preferences (perhaps for social desirability reasons) rather than those who state preferences for racial homophily or heterophily. Although we cannot entirely rule out potential social desirability bias, we note that patterns we observe are consistent with the demographic gender-racial partnership outcomes found in other studies. Moreover, findings based on heterosexuals' stated racial preferences (Feliciano et al. 2009) and same-sex couples (Schwartz and Graf 2009) are consistent with those based on online dating behaviors (Lin and Lundquist 2013), suggesting stated preferences generally conform to behaviors.

Match.com does not impose sexual identity categories. Our sampled daters indicate they are women seeking women or men seeking men. These categories do not necessarily map neatly on to lesbian or gay identities, which minorities may be less likely to adopt (Boellstorff 2011). However, the qualitative analysis of profile data suggests that nearly all daters described themselves as gay or lesbian, with the exception of a small number who identified as bisexual. ${ }^{\text {viii }}$

\section{Quantitative Variables and Analysis}

From the profiles, we coded all demographic information about the dater and the characteristics they seek in a date. Daters are asked to state a preference for a number of characteristics they look for in a date, including ethnicity. If they choose to override the default option, "any", they can select one or more of a number of ethnicities, including Asian, Black/African descent, East Indian, Latino/Hispanic, Middle Eastern, Native American, Pacific Islander, White/Caucasian, and Other.

Because previous research has indicated that personal characteristics shape racial preferences (Feliciano et al., 2011; Feliciano et al., 2009; Wilson et al., 2009), we controlled for the dater's age, region, education, body type, height, political views, and religion (see Supplemental Table 3 for coding and sample characteristics by race and gender).

To account for the possibility that daters use race as a proxy for preferences for other characteristics, we control for whether the dater stated preferences for education, religion, height or body type. We also controlled for how choosy the dater was overall, based on the percentage of items for which the dater expressed a preference. We also considered that racial preferences might result from exposure to different racial groups by controlling for the racial composition of the dater's community of residence. Using the 2010 Census, we collected data on the percent non-Hispanic White, percent non-Hispanic Black, percent Latino, and percent Asian in each town/municipality. ${ }^{\text {ix }}$ Based on the dater's own race, we created a variable for the percentage of their own racial group in their community.

We used multinomial regression to analyze racial homophily and heterophily using a three category outcome: whether daters prefer their own racial-ethnic group only (homophily), exclude their own racial-ethnic group (heterophily), or prefer their own racial-ethnic group and others or have no stated racial preference. ${ }^{x}$ Our definitions of homophily and heterophily are strict in the sense that they refer to preferring to date only one's own racial-ethnic group and only others, respectively. Our models permit direct comparison of gays' and lesbians' preferences, though we also run separate models by gender to examine differences in covariate effects (Supplemental Tables 5 and 6). We also ran additional descriptive analyses of the particular racial group preferred for those who excluded their own racial group.

\section{Qualitative Data}


We then qualitatively analyzed the textual portion of daters' profiles to reveal which kinds of discourse permeate the quantitative patterns. Daters are prompted by Match.com to write open-ended text entries describing themselves and their ideal partners. Although some users wrote shorter profiles with just a few sentences, most provided detailed information.

We took random, stratified samples from profiles of White, Black, Asian, and Latino/a gays and lesbians from our major outcomes of interest in the quantitative analyses - those who only preferred their own racial group (homophily) and those who only preferred others (heterophily). We sampled up to 40 daters from each outcome within each racial-ethnic and gender group for a total $\mathrm{N}$ of 456 . Not all categories had 40 daters in the sample; in those instances, we include all users. We coded the open-ended text entries from the profiles using Dedoose, a mixed methods software application. Dedoose enabled a fluid back-and-forth between deductive and inductive analysis. Each qualitative profile was linked to its quantitative counterpart from the previous analyses, enabling us to code profile texts and later observe how these emergent, qualitative themes correlated with racial homophily/heterophily.

We selected profiles in random order without knowledge of their preferences from the close-ended portion of the profiles. In order to minimize bias in coding, only the open-ended text portion of the profiles was visible. We initially coded the profile data through line-by-line opencoding, creating codes for broad categories that emerged (e.g., gender, interests, preference for a date). We then broke these open codes down into focused codes, providing more detailed categorizations of the themes emerging in the data (e.g., prefers a masculine date, considers themselves to be feminine, etc.). After coding was complete, we used Dedoose to compare which codes were differently applied across our outcome variable: racial heterophily or homophily. Final comparisons emerged from the most frequently discussed themes across all sampled profiles that were tied to homophilous and heterophilous race preferences.

\section{Results}

\section{Quantitative Analysis of Racial Preferences}

Figure 1 shows that the percentage of daters who state racial preferences (vs. keeping the default option, date "any" race) differs by gender within racial-ethnic groups, with gays significantly more likely to state racial preferences than lesbians. White gays express racial preferences just over ten percent more than do White lesbians, Black gays just under twelve percent more than Black lesbians, and Latino gays just over seven percent more than Latina lesbians. With the exception of Asians, gender differences are significant. At first glance, these findings appear at odds with existing work indicating that gays are more likely to interracially couple than lesbians. However, these findings are consistent with our expectation that gays' tendency towards interracial coupling may have less to do with racial openness in general than tastes for specific other racial groups.

Figure 2 shows the results of the multivariate analysis of racial homophily and heterophily. Results are shown as predicted probabilities of preferring one's own racial group only (homophily) and preferring only other racial groups (heterophily) after controls are applied (see Supplemental Table 4 for the full model). We see that, consistent with existing work on interracial unions and theories of racial hierarchies and group position, Whites are more likely than minorities to prefer their own racial group only and less likely to exclude their own racial group. For example, the probability of preferring only their own race is .17 among White gays, 
compared to only .04 among Asian gays, while the probability of excluding their own race is .03 and .13 among White gays and Asian gays, respectively. In another example, the probability of preferring only their own race is. 17 among White lesbians, while the probability of excluding their own race is .01 and .05 among White lesbians and Asian lesbians, respectively.

We also see significant gender differences. Lesbians, across all racial groups, are less likely than gays to exclude their own race. Asians are the most self-exclusionary group, which suggests that they conform to homonormative ideals that position Asians as less desired. Minority lesbians are slightly more likely than minority gays to prefer to only date within their racial group, although gender differences are only significant among Latinos. More striking is that Asian, Black, and Latino gays are significantly more likely to exclude their own racial group than are lesbians within the same racial group. In particular, Asian and Black gays exclude their own racial group at relatively high rates: Asian gays exclude their own race nearly five times more than do White gays, and Black gays exclude their own race just over two and a half times more than do White gays. Racial hierarchies are indeed gendered as work on heterosexuals suggests (Jacobs and Labov 2002; Robnett and Feliciano 2011). However, minority gays subscribe more to racial hierarchies than minority lesbians.

Table 1 shows that racially heterophilous gays and lesbians of color strongly prefer to date Whites over any other racial group. However, the pattern is far more pronounced for gays and is especially striking among Asian gays who self-exclude, 97\% of whom prefer White men. A focus on gay minorities' racial preferences thus reveals that dating markets are not as constrained for White lesbians and gays as suggested by other work (Lundquist and Lin 2015). Rather, this provides further support for existing theories of race- and gender-based hierarchies, as well as for theories of internalized racism and homonormativity that suggest racialized ideals structure the preferences of gays more than lesbians. Of additional note are the gendered patterns of exclusion of Blacks by heterophilous Asians and Latinos: about $2 \%$ of Asian gays and $4.9 \%$ of Latino gays are open to Blacks, compared with $8.7 \%$ of Asian lesbians and $8.3 \%$ of Latina lesbians. These findings reveal how racial markets are structured by racialized and gendered ideals even among minorities.

\section{Qualitative Analysis: Minority Daters}

Our grounded, qualitative analysis of profile texts sampled from both key categories those open only to dating racial others and those open only to dating the same race - uncovered how norms embedded in discourse structure these preferences. The qualitative analyses also yielded substantially different dating narratives for minorities versus Whites, regardless of gender.

Interestingly, daters rarely discussed race and racial preferences in their profiles, with the notable exception of Whites who prefer minorities. No minority daters discussed why they excluded their own racial-ethnic group or preferred Whites. It may be that daters may prefer not to discuss race for fear their rejection of minorities may be seen as racist (Bonilla-Silva and Forman 2000) ${ }^{\mathrm{xi}}$. Yet, gender, that is, preferences for masculinity or femininity, was the most frequently discussed topic in daters' profiles, and gender talk was especially common among minority gays who self-exclude. The top panel of Figure 3 shows that minority gays and lesbians who self-exclude are much more likely to discuss gender in their profiles as compared with their same-gender counterparts who prefer to in-date. The pattern is most salient among minority gays (who are also much more likely than their female counterparts to self-exclude): over $77 \%$ of 
those who exclude their own racial-ethnic group discuss masculinity in their profiles, as compared with $6 \%$ among those who prefer to in-date.

Many of the self-exclusionary minority gays express that they are masculine and/or prefer masculinity in an ideal partner, two orientations to masculinity (the self and preferences for others) seen as indicative of a homonormative commitment (Ascencio 2011, Collins 2009). In one example, an Asian gay man who excludes Asians provides his self-assessment:

I am an Asian who is not really into the scene, successful, sane, independent, masculine, straight acting, confident, a hard worker (self-employed), and more of a perfectionist type of guy. (Emphasis added)

In another example, a Black gay man who excludes Blacks provides his own self-assessment as well as preferences for a partner:

Hello, I'm a masculine male that enjoys movies, comedy and music...Looking to meet a fun loving masculine man that simply enjoys life and is open to dating and moving toward a LTR. (Emphasis added)

An intersectional analysis highlights a difference in how the two men above invoke homonormative masculine self-descriptions. Both men seek to distance themselves from pervasive racial-ethnic stereotypes. However, the stereotypes differ. Previous research examining the content of online ads posted by gays shows that preferences for Blacks, Asians, and Latinos are highly stereotyped: "Asians as exotic, docile, loyal partners; Hispanics as passionate, fiery lovers; and Blacks as 'well-endowed,' forbidden partners” (Phua \& Kaufman 2003: 992). Combatting the view of Asian American men as effeminate, the Asian American dater seeks to show strength. The African-American dater seeks to humanize himself to challenge the notion that he is hypersexual and only suitable for sexual encounters. Black masculinity does not appear to fit a homonormative ideal on Match.com, a website for more serious-minded daters, in contrast to existing work analyzing classified ads for men seeking sex (Logan 2010; Ward 2008).

Minority gays who exclude their own racial-ethnic group discuss preferences for ideal types of masculinity, which are typically tied to athleticism and imitating straightness. Some minority gays are even specific enough to note a preference for "straight-acting" partners. Some daters also express preferences for masculinity that overlap with a desire for a manly caretaker:

I'd like to find a guy who can handle himself, not a princess like all the others and he's manly... Someone who holds me at night...the perfect man. (Latino gay, excludes own; Emphasis added)

Like the Latino man above, many of the minority men's profiles also describe preferences for masculinity via a rejection of femininity in their potential date ("not a princess"). These same daters who minimize interests in effeminacy pursue White ideals through their preference for Whites in the quantitative portion of their profiles. Thus, these findings extend theories of homonormativity to include not only practices of self-regulation but also sexual and romantic desire for ideal others.

While minority lesbians are far less likely than minority gays to exclude their own racialethnic group, those that do self-exclude similarly discuss gender. Common gender subcodes 
among lesbians who exclude their own race-ethnicity include preferences for dates who are feminine, athletic, and sexual, and self-descriptions as "feminine" and "no drama," as well as loving and nice. A Black lesbian who excludes Blacks provides the following statement:

I'm looking for a woman who is feminine (a must, I'm only into women who look and act like women) lesbian, comfortable with herself, open-minded, kind, generous, someone who loves to laugh out loud and have fun and has inner strength. (Emphasis added)

Another dater, a Latina lesbian who excludes Latinas, expressed that she is looking for someone who is "feminine," but who is "not afraid to get their hands dirty and take charge every once in a while." These findings reveal preferences among racially heterophilous minority gays and lesbians who self-exclude that are consistent with homonormative ideals: they prefer either masculine men or feminine women. ${ }^{\text {xii }}$ Moreover, among both minority lesbians and gays who self-exclude and state a preference for Whites, desire for regular men or women is layered with talk about ideal types of masculine men or feminine women, suggesting they view Whites as both normative and ideal.

\section{Qualitative Analysis: White Daters}

As the bottom panel of Figure 3 shows, White gays who prefer only other Whites differ little from White gays who exclude their own in terms of gender talk. Most White gays discussed preferences for gender ideals in ways that were similar to self-exclusionary minority men's talk of preference for masculine men. For example, one White gay dater who prefers only Whites described himself as "very masculine (I can work on cars and home projects) and very much a man's man." Another White gay man who prefers to date Whites noted that he tends "to like men who are masculine/fit/thick/beefy/athletic/in shape versus obese-sorry to be so direct, just my taste."

Race and gender intersect in determining who is most likely to conform to homonormative ideals. To a lesser extent than White males, but more than minority females and minority males, White lesbians who prefer to date only Whites expressed preferences for homonormative ideals, as one woman noted that she is "very attracted to femininity," and another expressed that her "ideal girl would be a femme." Although, for purposes of analysis, too few White lesbians prefer people of color, these findings are consistent with a hierarchy in which gender overlaps with Whiteness as an ideal. Research suggests that "femme" women, who present a more feminine appearance, dress, and manner, are more desired than are "butch" women, who adhere to a masculine appearance, manner, or dress (Smith \& Stillman 2002). Historically, butch and femme practices were modeled after the behaviors and portrayals of actresses and actors in Hollywood films who are overwhelmingly White (Kennedy \& Davis 1993). Thus, conceptions of beauty may be closely tied to racialized femininities.

Of note are the few White gay male daters who exclude their own racial group. Whereas other daters by and large do not discuss preferences for race in their profiles, these selfexclusionary White gays are very explicit about their racial tastes. In one example, a selfexclusionary White gay described himself as a Latinophile: 
Gym rat, show tunes aficionado, and Latinophile. Some think I'm butch...I love working on my house, landscaping, being outside, working out (weights) and singing. I'm a waspy guy from Arkansas. (White gay, excludes own; emphasis added)

Although waspy and White, this dater blends preferences for Latinos with self-descriptions of butch masculinity. This is similar to the White gay expatriates described by Collins (2009) whose pursuit of minorities aids in the production of their own White masculinity. Another selfexclusionary White gay man explains that his fascination for Africa connects to his taste for Black men: "I'm very into international work, particularly Africa...I was a Peace Corps volunteer, lived there for two years. These experiences made me really fond of Black men". Thus, Blacks are essentialized as a desirous group because of his own social interests in Africa. Rather than racial openness suggested by recent work on gay partnership outcomes, daters have specific racial preferences that are tied to different experiences or meanings associated with other racial groups.

Other self-exclusionary White gay daters hypersexualize Black men. One White gay man said he is a "White for Black top, Black, or Black mix only - no exceptions. I am a great cook and homemaker for my partner". In another similar example, a White gay dater who only prefers Blacks desires Blacks for their sex drive and assertiveness:

I love for you to hold my hand and make out and of course have a high sex drive like me. Lookin' for a freak...lol...I am a bottom that is drawn to Black men. I love the way our skin looks together.

As Logan (2010) finds in his study of sex workers, Black men are desired by White gays when they conform to hypersexual and dominant roles. We did not find similar patterns, however, among Black daters. These excerpts resonate with much existing qualitative work on the prevalence of sexual racism in the gay community, and minority gays' experiences with racial, gendered, and sexual exoticization by White gays. It also firmly aligns with theories of homonormativity: even when Whites desire minority men, they do so through a lens of normativity that positions White as normative and minorities as exotic. This pattern, however, was not prevalent among White lesbians, only a handful of whom prefer to only date nonWhites.

\section{Discussion and Conclusion}

Using a unique dataset collected from Match.com, this study suggests that gay daters' tendency toward interracial dating is often not motivated by racial openness but rather by cultural norms that position gendered aspects of Whiteness, and especially White masculinity, as most desirable. Existing work argues that lesbians and gays are more likely to interracially couple than heterosexuals because they have greater social opportunities as a consequence of living in racially diverse urban areas and using the internet to date. By examining the racial preferences that motivate such pairings, we find that lesbians and gays, especially, are actually quite racially selective. Like heterosexual Whites (Robnett and Feliciano 2011), gay Whites are more racially homophilous, preferring to date only their own race, than minorities are, consistent with the theory that Whites maintain their own social position through prejudice toward minorities. Thus, although some of the daters in our sample comment that their preferences are individual ("no 
offense, it's just my type"), the patterns of race- and gender-based preferences reflect and perpetuate existing systems of inequality (Bourdieu 2001).

Existing studies of interracial unions cannot explain why lesbians are less likely than gays to be in interracial relationships, nor do they fully account for how race and gender relate to normative constructions of romantic ideals (Pyke 2010b). Theories of homonormativity suggest that gays and lesbians may abide by a set of norms generative of a racialized and gendered hierarchy (Duggan 2002). Gay men and lesbians of color are much more likely to exclude their own racial-ethnic group than are White lesbians and gays. This finding suggests some internalized racial oppression (Pyke 2010a), but this appears to be gendered. Asian and Black gays exclude their own race at rates much higher than lesbians of the same racial-ethnic group. Whiteness is also the preferred race. Racial self-exclusion is most striking among minority Asian gays, who overwhelmingly prefer Whites, suggesting that, like Asian heterosexual women, Asian gays internalize negative stereotypes of themselves as less masculine or desirable while White men are ideal (Pyke 2010b). These findings suggest one mechanism to explain why demographers have found that gays interracially couple more than lesbians do (Schwarz and Graf 2009): despite lesbians' greater tendency to state openness to dating all racial groups, and minority gay and lesbians' similar rates of homophily, gays may be more likely to interracially date because minority gays more often prefer to only date Whites. Given our findings, if some minorities only want to date Whites, these minorities will likely end up interracially coupled because, as suggested by our own data, at least some Whites are open to dating minorities. The alternative is that heterophilous minorities end up dating no one, which is unlikely. Thus, it is reasonable to expect that this pattern leads to interracial coupling, and higher rates of interracial coupling among gays then lesbians. Future work, however, could further document the lived experience of heterophilous minorities given such preference constraints to understand partnership outcomes.

Qualitative analyses help explain what drives quantitatively observed patterns in racial heterophily. Gay men of color who exclude their own racial-ethnic group describe themselves and their ideal partners as masculine and straight acting. Though far fewer in number, lesbians of color who exclude their own racial-ethnic group describe their ideal partners as feminine. Homophilous White gays and lesbians also express preferences for masculine men or feminine women, respectively, but the few White gays who prefer only minority dates describe their preferences in ways that position Whiteness as normative and minorities as exotic Others.

Theories of culture and power argue that these subconscious desires are a product of collectively produced and drive social patterns, however we find that gays conform to this pattern more than do lesbians (Bourdieu 2001). In line with theories of homonormativity, heterophilous minority same-sex daters may draw on discourses of idealized masculinity or femininity. It may also be that heterophilous minority gays and lesbians are conforming to the discursive norms of Whites, the desired group. In other words, if White masculinity or femininity is a normative ideal then heterophilous minority daters may talk more about desire for masculinity or femininity as a consequence of this conformity. In addition, we find that body type preferences are associated with racial self-exclusion (Supplementary Table 4). Selfexclusionary daters of color may be drawing upon ideas about idealized femininity or masculinity which are also tied to ideal body types (Baker 2005; Thorne and Coupland 1998). This suggests that race and body type preferences may be intertwined with the aforementioned racial and gendered ideals.

Our findings stand in contrast to a recent study by Lundquist and Lin (2015) showing that 
White lesbians are more racially open than are White gays, a finding inconsistent with Census patterns showing White gays are more likely to interracially couple than White lesbians. Instead, consistent with the gendered patterns of interracial same-sex unions, we find that White gays are more likely to prefer minorities than White lesbians are, and, more importantly, that minority gays are more heterophilous in favor of Whites than are lesbians. The difference may be attributed to two factors. First, Match.com daters may be more oriented towards long-term relationships than the daters on the (unnamed) website examined by Lundquist and Lin (2015). Second, and more importantly, by not including minority daters' preferences, Lundquist and Lin (2015) miss that White gays, to a greater extent than White lesbians, are more often the only racial group desired by minority men, reflecting their status as racialized and gendered ideals.

Despite research from lesbian studies, we did not find much discussion of masculinity or pursuit of butch/femme pairings. This may suggest, as Moore (2008) argues in her work on Black lesbians, that gender roles among lesbians may not necessarily drive inequality. For example, Farr (2011) shows how the deployment of a tomboy identity among lesbian daters is a desired gender performance that is transgressive rather than homonormative. We find that the few who express tomboy identities or preferences in their profiles were not racially selfexclusionary, suggesting that certain non-feminine gender expressions among lesbians conform less to homonormative ideals.

Our study has a number of limitations that may prove fruitful avenues for future work. For example, we focus on samples of daters from major metropolitan areas, and our sample was all collected during a one-month period which may obscure effects of seasonality (Marky and Markey 2013). Another limitation is that we did not collect data from other dating websites for comparative analysis, which may cater to different audiences or types of romantic or sexual pursuits. Our data also did not allow us to examine gendered and racial preferences that designate role/sex position that have been found to matter for gays' racial preferences (Logan 2010). Given that existing work finds that sex role preferences are tied to racial hierarchies, it may be that those who conform to top/bottom are also conforming to homonormative ideals in some capacity. Future work could test this possibility and potentially reveal yet another layer of intersectionality that shows how desire for particular social and cultural categories are tied to inequality.

The findings in this article contribute to a more nuanced understanding of how gendered normative commitments spur racial tastes in the same-sex dating market. Existing work that examines interracial unions, rather than the preferences that drive these pairings, provides a limited view of racial and gendered attitudes in the dating market. Through our mixed methods analysis of daters' preferences we are able to observe that people have clearly delimited raceand gender-based ideals. Rather than psychologize and blame individuals for their romantic tastes, we encourage researchers to explore how culture operates not only at group-levels of race, gender, and sexuality, but also at the level of hetero- and homonormative institutions (Bourdieu 2001; Schmitz 2012). How do daters of the same race come to have different romantic preferences? How, if at all, have increased gains in gay rights such as the right to marry influenced the spread and conformity to institutional ideals? As theories of homonormativity suggest, we might consider that greater incorporation into society may have not only benefits but also costs - among them, the narrowing of desires and subsequent opportunities for love. 


\section{REFERENCES}

Anon. 2012. “The Top 5 Gay Dating Sites.” HIM Magazine. Retrieved 25 October 2014. (http://www.him-magazine.com/2012/01/01/the-top-5-gay-dating-sites/)

Asencio, Marysol. 2011. "'Locas,' Respect, and Masculinity: Gender Conformity in Migrant Puerto Rican Gay Masculinities." Gender \& Society 25(3): 335-354.

Baker, Paul. 2005. Public Discourses of Gay Men. New York: Routledge.

Bobo, Lawrence D and Massagli, Michael P. 2001. "Stereotyping and urban inequality." Pp. 89162 in Urban Inequality: Evidence from four cities, edited by A. O'Connor, C. Tilly, and L. Bobo. Lawrence D. Bobo and Michael P. Massagli. New York: Russell Sage Foundation.

Boellstorff, Tom. 2011. "But Do Not Identify as Gay: A Proleptic Genealogy of the MSM Category." Cultural Anthropology 26(2): 287-312.

Bonilla-Silva, Eduardo and Forman, Tyrone. (2000. "II Am Not a Racist But...': Mapping White College Students' Racial Ideology in the USA.” Discourse \& Society 11(1): 58-85.

Bourdieu, Pierre. 2001. Masculine Domination (1 ${ }^{\text {st }}$ Edition). Cambridge: Polity Press.

Bryant, Karl. 2008. "In Defense of Gay Children? 'Progay' Homophobia and the Production of Homonormativity." Sexualities 11(4): 455-475.

Chauncey, George. 1999. Gay New York: Gender, Urban Culture and the Making of the Gay World, 1890-1940. New York: Basic Books.

Collins, Dana. 2009. “'We're There and Queer': Homonormative Mobility and Lived Experience among Gay Expatriates in Manila." Gender \& Society 23: 465.

Collins, Patricia Hill. 2004.Black Sexual Politics. New Jersey: Routledge Press.

Coltrane, Scott , and Melinda Messineo. 2000. "The Perpetuation of Subtle Prejudice: Race and Gender Imagery in 1990s Television Advertising." Sex Roles 42(5/6):363-389.

Connell, Raewynn. 2005. Masculinities. Berkeley: University of California Press.

Duggan, Lisa. 2002. The new homonormativity: The sexual politics of neoliberalism. Durham, NC: Duke University Press.

eBiz, The eBusiness MBA Guide. 2015. "Top 15 Most Popular Dating Websites." vol. 2015. http://www.ebizmba.com/articles/dating-websites.

Eng, David L. 2010. The Feeling of Kinship: Queer Liberalism and The Racialization of Intimacy. Durham, NC: Duke University Press.

Farr, Daniel. 2011. "Online Women-Seeking-Women Personal Ads and the Deployment of 'Tomboy' Identities.” Journal of Lesbian Studies 15(4): 493-506.

Feliciano, Cynthia, Rennie Lee, and Belinda Robnett. 2011. "Racial Boundaries among Latinos: Evidence from Internet Daters' Racial Preferences.” Social Problems 58(2): 189-212.

Feliciano, Cynthia, Belinda Robnett, and Golnaz Komaie. 2009. "Gendered racial exclusion among White Internet daters." Social Science Research 38(1):39-54.

Firebaugh, Glenn, and Kenneth E. Davis. 1988. "Trends in AntiBlack Prejudice, 1972-1984: Region and Cohort Effects." American Journal of Sociology 94 (2): 251- 72.

Fox, Susannah. 2005. "Digital Divisions." Available at: (http://www.pewInternet.org/Reports/2005/Digital-Divisions.aspx).

Gamson, Joshua. 1998. Freaks Talk Back: Tabloid Talk Shows and Sexual Nonconformity. Chicago, Ill: University of Chicago Press. 
Gates, Gary J. 2006. "Same-sex couples and the gay, lesbian, bisexual population: New estimates from the American Communities Survey. Los Angeles: The Williams Institute.

Han, Chong-suk. 2006. "Geisha of a different kind: Gay Asian men and the gendering of sexual identity." Sexuality \& Culture 10(3): 3-28.

Hitsch, Gunter J., Ali Hortascsu and Dan Ariely. 2010. "What Makes You Click? Mate Preferences in Online Dating." Quantitative Marketing and Economics 8(4):393-427.

Hunter, Margaret L. 2002. "'If You're Light You're Alright': Light Skin Color as Social Capital for Women of Color." Gender \& Society 16(2): 175-193.

Jacobs, Jerry A. and Teresa G. Labov. 2002. "Gender Differentials in Intermarriage among Sixteen Race and Ethnic Groups." Sociological Forum 17:621-46.

Kalmijn, Matthijs. 1998. "Intermarriage and Homogamy: Causes, Patterns, Trends." Annual Review of Sociology 24:395-421.

Kalmijn, Matthijs, and Henk Flap. 2001. “Assortative Meeting and Mating: Unintended Consequences of Settings for Partner Choices." Social Forces 79(4): 1289-1312.

Kastanis, Angel and Wilson, Bianca. 2014. "Race/Ethnicity, Gender and Socioeconomic Wellbeing of Individuals in Same-sex Couples." Los Angeles: The Williams Institute.

Kennedy, Elizabeth Lapovsky and Madeline D. Davis. 1993. Boots of Leather, Slippers of Gold: The History of a Lesbian Community. New York: Routledge.

Lin, Ken-Hou and Jennifer Lundquist. 2013. "Mate Selection in Cyberspace: The Intersection of Race, Gender, and Education.” American Journal of Sociology 119(1): 183-215.

Logan, Trevon. D. 2010. "Personal Characteristics, Sexual Behaviors, and Male Sex Work: A Quantitative Approach.” American Sociological Review 75(5):679-704.

Lundquist, Jennifer H. and Ken-Hou Lin. 2015. "Is Love (Color) Blind? The Economy of Race among Gay and Straight Daters." Social Forces 93:1423-1449.

Markey, Patrick, and Charlotte Markey. 2013. "Seasonal Variation in Internet Keyword Searches: A Proxy Assessment of Sex Mating Behaviors." Archives of Sexual Behavior 42(4): 515.

Martin, Steven P., and John P. Robinson. 2007. "The Income Digital Divide: Trends and Predictions for Levels of Internet Use." Social Problems 54(1):1-22.

Moore, Mignon R. 2008. "Gendered power relations among women: A study of household decision making in Black, lesbian stepfamilies.” American Sociological Review 73(2):335-356.

O'Brien, Eileen. 2008. The Racial Middle: Latinos and Asian Americans Living Beyond the Racial Divide. New York: New York University Press.

Phua, Vons C., and Gayle Kaufman. 2003. "The Crossroads of Race and Sexuality: Date Selection among Men in Internet 'Personal' Ads.” Journal of Family Issues 24(8):981994.

Pyke, Karen D. 2010a. "What is Internalized Racial Oppression and Why Don't We Study it? Acknowledging Racism's Hidden Injuries.” Sociological Perspectives 53(4): 551-572.

Pyke, Karen D. 2010b. "An Intersectional Approach to Resistance and Complicity: The Case of Racialised Desire among Asian American Women.” Special Issue: Women, Intersectionality and Diasporas, Journal of Intercultural Studies 31(1):81-94.

Ramsdale, Suzannah. 2014. "Online Dating: The 11 Best Sites." Marie Claire. Retrieved 25 October 2014. (http://www.marieclaire.co.uk/blogs/suzannah-ramsdale/541693/onlinedating-the-11-best-sites.html) 
Rich, Adrienne. 1980. "Compulsory heterosexuality and lesbian existence." Signs 5(4):631-660. Robnett, Belinda, and Cynthia Feliciano. 2011. "Patterns of Racial-Ethnic Exclusion by Internet Daters." Social Forces 89(3): 807-282.

Rosenfeld, Michael J., and Byung-Soo Kim. 2005. "Young Adult Relationship Values at the Intersection of Gender and Sexuality." Journal of Marriage and the Family 71(3): 510525.

Rosenfeld, Michael J. and Thomas, Rueben. J. 2012. "Searching for a Mate: The Rise of the Internet as a Social Intermediary." American Sociological Review 77(4): 523-547.

Rudder, Christian. 2009. "How Race Affects the Messages You Get." OkTrends: Dating Research from OkCupid. Retrieved 25 October 2014. (http://blog.okcupid.com/index.php/your-race-affects-whether-people-write-you-back/)

Sautter, Jessica M., Rebecca M Tippet, and S. Philip Morgan. 2010. "The Social Demography of Internet Dating in the United States." Social Science Quarterly 91:554-575.

Schmitz, Andreas. 2012. "Elective Affinities 2.0? A Bourdieusian Approach to Couple Formation and Methodology of E-Dating." Social Science Research on the Internet (RESET) 1(1): 175-202.

Schwartz, Christine R., and Nikki L. Graf. 2009. "Assortative Matching Among same-Sex and Different-Sex Couples in the United States, 1990-2000.” Demographic Research 21: 843878.

Smith, Christina A. and Shannon Stillman. 2002. "Butch/Femme in the Personal Advertisements of Lesbians." Journal of Lesbian Studies 6(1): 45-51.

Steinbugler, Amy C. 2005. "Visibility as Privilege and Danger: Heterosexual and Same-Sex Interracial Intimacy in the $21^{\text {st }}$ Century." Sexualities 8(4): 425-443.

Stokes, J. P., \& Peterson, J. L. 1998. Homophobia, self-esteem, and risk for HIV among African American men who have sex with men. AIDS Education and Prevention, 10, 278-292.

Thorne, Adrian and Coupland, Justine. 1998. "Articulations of Same-sex desire: Lesbian and Gay Male Dating.” Journal of Sociolinguistics 2(2): 233-257.

Walker, Lisa L and Eller, Jackie L. 2015. "Raising Capital: Claims of Masculinity among Men on Match.com." Men and Masculinities 19(1): 42-63.

Warner, Michael. 1999. The Trouble with Normal: Sex, Politics, and the Ethics of Queer Life. Cambridge, MA: Harvard University Press.

Ward, Jane. 2008. "Dude-Sex: White Masculinities and 'Authentic' Heterosexuality Among Dudes Who Have Sex With Dudes." Sexualities 11(4):414-434.

Wilson, Bianca D. M. 2009. "Black lesbian sexual culture and lesbian gender: Celebration and resistance." Culture, Health, \& Sexuality, 11: 297-313.

Wilson, Patrick A., Valera, Pamela, Ventuneac, Ana, Balan, Ivan, Rowe, Matt, and CarballoDiéguez. 2009. "Race-based sexual stereotyping and sexual partnering among men who use the Internet to identify other men for bareback sex." Journal of sex research, 46(5): 399-413.

Yancey, George. 2003. Who Is White?: Latinos, Asians, And the New Black/nonblack Divide. Boulder: Lynne Rienner Publishers, Inc. 


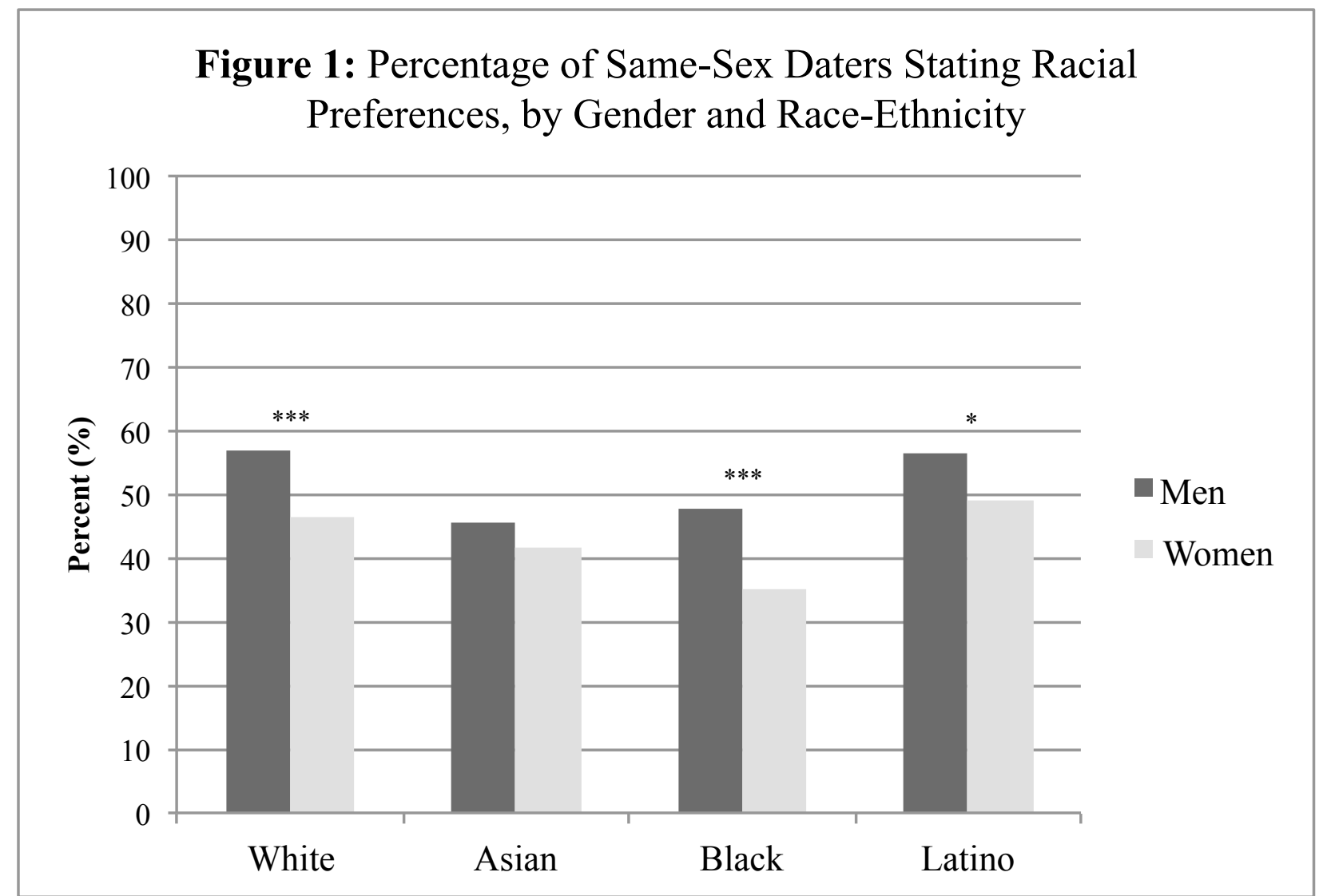

Note: Chi $^{2}$ tests are shown indicating significant gender differences within racial-ethnic groups for stating a racial-ethnic preference. ${ }^{*} p<.05 * * p<.01 * * * p<.001$. 


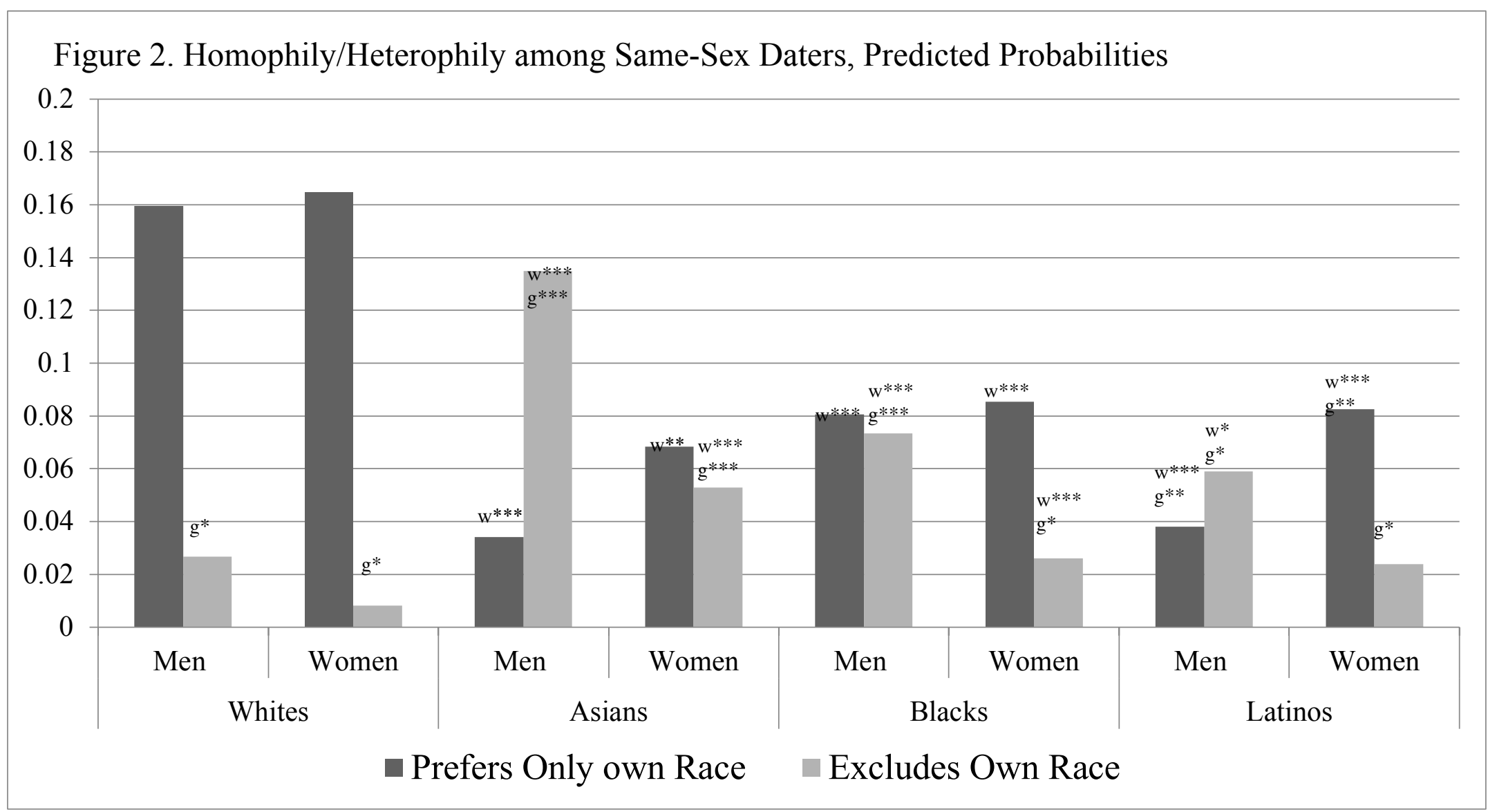

Note: Based on full models (shown in Supplemental Table 4) with significant interactions of race and gender, controlling for age, region, education, income, body type and body type preference, height and height preference, politics, religion, racial composition of daters' city of residence, preferences for faith and education, and overall choosiness. Continuous variables are set at the mean, others set at most common categorical values. $w=$ significant differences in preferences with same-gender Whites, $g=$ significant gender differences in preferences within raceethnicity. To simplify, the prefers own \& others or any outcome are not shown. ${ }^{*} p<.05 * * p<.01 * * * p<.001$. 
Figure 3: Gender Talk among Minority and White Same-Sex Daters, by Homophily and Heterophily

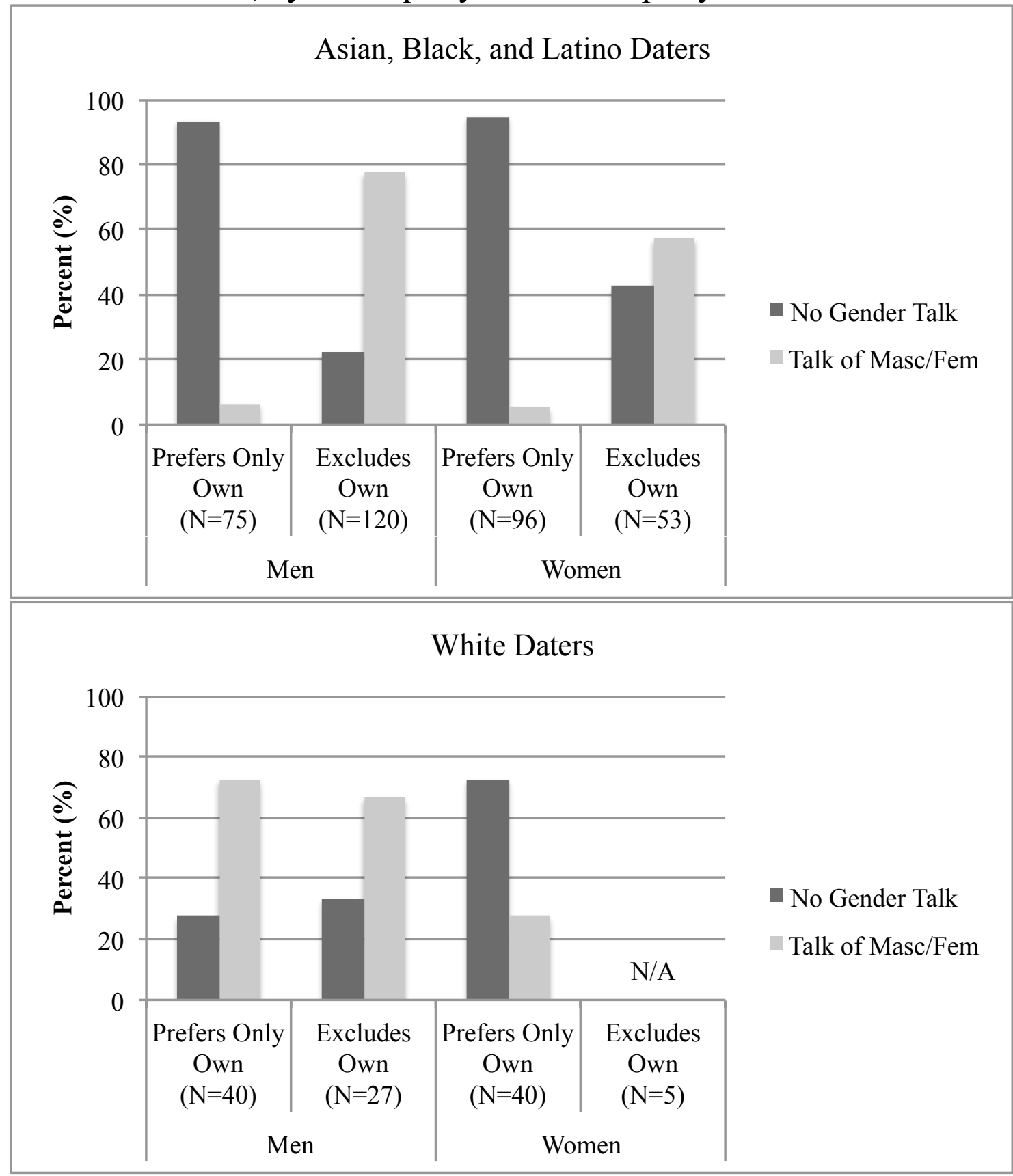

Note: Only daters from the qualitative samples of daters with sample sizes greater than 10 are shown. 
Table 1: Racial Preferences among Heterophilous Same-Sex Daters (Percentages)

\begin{tabular}{|c|c|c|c|c|c|c|c|c|}
\hline & \multicolumn{4}{|c|}{ Gay Men } & \multicolumn{4}{|l|}{ Lesbians } \\
\hline & Asian & Black & White & Latino & Asian & Black & White & Latina \\
\hline Prefers Whites & 97.06 & 87.88 & - & 90.24 & 82.61 & 61.11 & - & 66.67 \\
\hline Prefers Latinos & 36.27 & 72.73 & 62.96 & - & 47.83 & 44.44 & 44.72 & - \\
\hline Prefers Blacks & 1.96 & - & 59.26 & 4.88 & 8.70 & - & 54.77 & 8.33 \\
\hline Prefers Asians & - & 19.70 & 33.33 & 2.44 & - & 33.33 & - & 41.67 \\
\hline $\mathrm{N}$ & 102 & 66 & 27 & 41 & 23 & 18 & 5 & 12 \\
\hline
\end{tabular}


Supplemental Table 1: Racial Composition of Four Metropolitan Areas in Current Population Survey as Compared with Match.com

\begin{tabular}{|c|c|c|c|c|c|c|c|c|c|c|c|c|c|c|c|c|}
\hline & \multicolumn{4}{|c|}{ Los Angeles } & \multicolumn{4}{|c|}{ New York } & \multicolumn{4}{|c|}{ Chicago } & \multicolumn{4}{|c|}{ Atlanta } \\
\hline & $\begin{array}{l}\text { CPS 18+, } \\
\text { single }\end{array}$ & $\begin{array}{c}\text { CPS 18+, } \\
\text { single, } \\
\text { internet } \\
\text { users } \\
\end{array}$ & $\begin{array}{c}\text { Match.com - } \\
\text { all* } \\
\end{array}$ & $\begin{array}{c}\text { Match.com, } \\
\text { gays/lesbian } \\
\text { s }\end{array}$ & $\begin{array}{c}\text { CPS 18+, } \\
\text { single }\end{array}$ & $\begin{array}{c}\text { CPS } 18+, \\
\text { single, } \\
\text { internet } \\
\text { users } \\
\end{array}$ & $\begin{array}{c}\text { Match.com - } \\
\text { all* } \\
\end{array}$ & $\begin{array}{l}\text { Match.com, } \\
\text { gays/lesbian } \\
\text { s }\end{array}$ & $\begin{array}{c}\text { CPS 18+, } \\
\text { single }\end{array}$ & $\begin{array}{c}\text { CPS } 18+, \\
\text { single, } \\
\text { internet } \\
\text { users } \\
\end{array}$ & $\begin{array}{c}\text { Match.com - } \\
\text { all* } \\
\end{array}$ & $\begin{array}{l}\text { Match.com, } \\
\text { gays/lesbian } \\
\text { s }\end{array}$ & $\begin{array}{c}\text { CPS } 18+, \\
\text { single }\end{array}$ & $\begin{array}{c}\text { CPS 18+, } \\
\text { single, } \\
\text { internet } \\
\text { users }\end{array}$ & $\begin{array}{l}\text { Match.com - } \\
\text { all* }\end{array}$ & $\begin{array}{c}\text { Match.com, } \\
\text { gays/lesbian } \\
\text { s }\end{array}$ \\
\hline \multicolumn{17}{|l|}{ MALES } \\
\hline White & 0.38 & 0.44 & 0.48 & 0.30 & 0.44 & 0.49 & 0.51 & 0.51 & 0.56 & 0.62 & 0.62 & 0.63 & 0.51 & 0.54 & 0.59 & 0.52 \\
\hline Black & 0.11 & 0.09 & 0.02 & 0.10 & 0.20 & 0.18 & 0.10 & 0.06 & 0.22 & 0.19 & 0.10 & 0.09 & 0.35 & 0.32 & 0.22 & 0.22 \\
\hline Asian & 0.07 & 0.09 & 0.07 & 0.06 & 0.08 & 0.10 & 0.08 & 0.06 & 0.04 & 0.05 & 0.03 & 0.03 & 0.05 & 0.07 & 0.01 & 0.02 \\
\hline Hispanic & 0.43 & 0.36 & 0.25 & 0.33 & 0.28 & 0.24 & 0.11 & 0.23 & 0.17 & 0.14 & 0.14 & 0.16 & 0.10 & 0.07 & 0.05 & 0.09 \\
\hline Other & 0.01 & 0.02 & 0.17 & 0.20 & 0.00 & 0.00 & 0.21 & 0.14 & 0.00 & 0.00 & 0.11 & 0.09 & 0.01 & 0.01 & 0.13 & 0.14 \\
\hline $\mathrm{N}$ & 2941 & 2260 & 200 & 100 & 4080 & 3236 & 200 & 100 & 2072 & 1573 & 200 & 100 & 1086 & 866 & 200 & 100 \\
\hline \multicolumn{17}{|c|}{ FEMALES } \\
\hline White & 0.38 & 0.44 & 0.44 & 0.38 & 0.47 & 0.50 & 0.57 & 0.34 & 0.56 & 0.63 & 0.64 & 0.40 & 0.45 & 0.50 & 0.55 & 0.33 \\
\hline Black & 0.11 & 0.08 & 0.12 & 0.10 & 0.24 & 0.22 & 0.10 & 0.21 & 0.27 & 0.21 & 0.18 & 0.31 & 0.45 & 0.41 & 0.33 & 0.48 \\
\hline Asian & 0.11 & 0.13 & 0.09 & 0.06 & 0.07 & 0.08 & 0.06 & 0.01 & 0.02 & 0.03 & 0.00 & 0.01 & 0.04 & 0.05 & 0.03 & 0 \\
\hline Hispanic & 0.39 & 0.34 & 0.20 & 0.25 & 0.22 & 0.19 & 0.12 & 0.28 & 0.13 & 0.12 & 0.08 & 0.18 & 0.05 & 0.03 & 0.05 & 0.11 \\
\hline Other & 0.01 & 0.01 & 0.15 & 0.20 & 0.00 & 0.00 & 0.15 & 0.16 & 0.01 & 0.01 & 0.10 & 0.10 & 0.01 & 0.01 & 0.04 & 0.08 \\
\hline $\mathrm{N}$ & 3194 & 2442 & 200 & 100 & 4789 & 3654 & 200 & 100 & 2245 & 1657 & 200 & 100 & 1164 & 946 & 200 & 100 \\
\hline
\end{tabular}

Sources: Current Population Survey Computer \& Internet Use Supplement, Oct 2009 \& 2010, Match.com random sample drawn in 2011. Notes: CPS data are weighted to provide population estimates within each metropolitan area.

* Match.com data are weighted so that gays account for the approximate \% in the general populations of these regions based on estaimtes obtained from Gates (2006). 
Supplemental Table 2: Sample Characteristics by Race: Comparing Match.com Daters to Single Persons in the Current Population Survey

\begin{tabular}{|c|c|c|c|c|c|c|c|c|c|c|c|c|}
\hline & \multicolumn{3}{|c|}{ Whites } & \multicolumn{3}{|c|}{ Blacks } & \multicolumn{3}{|c|}{ Latinos } & \multicolumn{3}{|c|}{ Asians } \\
\hline & $\begin{array}{l}\text { CPS } 18+, \\
\text { single }\end{array}$ & $\begin{array}{c}\text { CPS 18+, } \\
\text { single, } \\
\text { internet } \\
\text { users* }\end{array}$ & $\begin{array}{c}\text { Match.com, } \\
18+\end{array}$ & $\begin{array}{l}\text { CPS } 18+, \\
\text { single }\end{array}$ & $\begin{array}{c}\text { CPS 18+, } \\
\text { single, } \\
\text { internet } \\
\text { users* }\end{array}$ & $\begin{array}{c}\text { Match.com, } \\
18+\end{array}$ & $\begin{array}{l}\text { CPS } 18+, \\
\text { single }\end{array}$ & $\begin{array}{c}\text { CPS 18+, } \\
\text { single, } \\
\text { internet } \\
\text { users* }\end{array}$ & $\begin{array}{c}\text { Match.com, } \\
18+\end{array}$ & $\begin{array}{l}\text { CPS } 18+, \\
\text { single }\end{array}$ & $\begin{array}{c}\text { CPS 18+, } \\
\text { single, } \\
\text { internet } \\
\text { users* }\end{array}$ & $\begin{array}{c}\text { Match.com, } \\
18+\end{array}$ \\
\hline \multicolumn{13}{|l|}{ MALES } \\
\hline Age & $\begin{array}{l}40.42 \\
(15.53)\end{array}$ & $\begin{array}{l}37.15 \\
(14.14)\end{array}$ & $\begin{array}{l}35.27 \\
(12.46)\end{array}$ & $\begin{array}{l}38.69 \\
(12.32)\end{array}$ & $\begin{array}{l}35.30 \\
(10.80)\end{array}$ & $\begin{array}{l}33.11 \\
(10.89)\end{array}$ & $\begin{array}{l}34.50 \\
(11.94)\end{array}$ & $\begin{array}{l}32.52 \\
(10.89)\end{array}$ & $\begin{array}{l}31.40 \\
(9.80)\end{array}$ & $\begin{array}{l}32.89 \\
(13.20)\end{array}$ & $\begin{array}{l}30.50 \\
(11.35)\end{array}$ & $\begin{array}{l}30.94 \\
(7.91)\end{array}$ \\
\hline \multicolumn{13}{|l|}{ Marital Status: } \\
\hline Never Married & 0.72 & 0.76 & 0.63 & 0.73 & 0.79 & 0.73 & 0.81 & 0.84 & 0.71 & 0.84 & 0.88 & 0.83 \\
\hline Separated & 0.03 & 0.03 & 0.05 & 0.06 & 0.05 & 0.06 & 0.08 & 0.06 & 0.08 & 0.04 & 0.03 & 0.06 \\
\hline Divorced & 0.17 & 0.15 & 0.23 & 0.16 & 0.12 & 0.19 & 0.09 & 0.09 & 0.19 & 0.06 & 0.06 & 0.10 \\
\hline Widowed & 0.08 & 0.06 & 0.09 & 0.05 & 0.03 & 0.02 & 0.03 & 0.01 & 0.02 & 0.06 & 0.03 & 0.01 \\
\hline \multicolumn{13}{|l|}{ Education: } \\
\hline High School Grad or Less & 0.34 & 0.28 & 0.12 & 0.51 & 0.41 & 0.18 & 0.67 & 0.56 & 0.21 & 0.24 & 0.19 & 0.06 \\
\hline Some College & 0.23 & 0.25 & 0.26 & 0.26 & 0.30 & 0.41 & 0.19 & 0.24 & 0.38 & 0.26 & 0.29 & 0.18 \\
\hline Associates & 0.07 & 0.07 & 0.09 & 0.09 & 0.09 & 0.11 & 0.05 & 0.06 & 0.10 & 0.07 & 0.06 & 0.05 \\
\hline Bachelor's Degree & 0.26 & 0.29 & 0.34 & 0.11 & 0.15 & 0.21 & 0.08 & 0.10 & 0.20 & 0.31 & 0.34 & 0.41 \\
\hline Graduate Degree & 0.07 & 0.08 & 0.15 & 0.02 & 0.03 & 0.09 & 0.02 & 0.03 & 0.09 & 0.11 & 0.12 & 0.25 \\
\hline PhD/Professional Degree & 0.02 & 0.02 & 0.04 & 0.00 & 0.01 & 0.01 & 0.00 & 0.00 & 0.02 & 0.00 & 0.00 & 0.05 \\
\hline $\mathrm{N}$ & 5372 & 4540 & 1451 & 1248 & 872 & 1280 & 2548 & 1644 & 1679 & 966 & 843 & 995 \\
\hline \multicolumn{13}{|l|}{ FEMALES } \\
\hline Age & $\begin{array}{l}46.92 \\
(18.19)\end{array}$ & $\begin{array}{l}41.67 \\
(16.04)\end{array}$ & $\begin{array}{l}35.23 \\
(12.11)\end{array}$ & $\begin{array}{l}44.64 \\
(14.30)\end{array}$ & $\begin{array}{l}41.6 \\
(16.04)\end{array}$ & $\begin{array}{l}34.53 \\
(10.49)\end{array}$ & $\begin{array}{l}40.08 \\
(15.34)\end{array}$ & $\begin{array}{l}38.35 \\
(14.46)\end{array}$ & $\begin{array}{l}32.17 \\
(10.44)\end{array}$ & $\begin{array}{l}42.94 \\
(17.18)\end{array}$ & $\begin{array}{l}40.26 \\
(16.42)\end{array}$ & $\begin{array}{l}32.99 \\
(8.48)\end{array}$ \\
\hline \multicolumn{13}{|l|}{ Marital Status: } \\
\hline Never Married & 0.53 & 0.61 & 0.62 & 0.60 & 0.63 & 0.67 & 0.59 & 0.62 & 0.65 & 0.62 & 0.67 & 0.72 \\
\hline Separated & 0.04 & 0.04 & 0.05 & 0.04 & 0.07 & 0.05 & 0.12 & 0.10 & 0.07 & 0.05 & 0.04 & 0.05 \\
\hline Divorced & 0.21 & 0.21 & 0.28 & 0.21 & 0.19 & 0.24 & 0.18 & 0.19 & 0.26 & 0.13 & 0.12 & 0.20 \\
\hline Widowed & 0.22 & 0.14 & 0.05 & 0.15 & 0.11 & 0.04 & 0.10 & 0.09 & 0.02 & 0.21 & 0.17 & 0.02 \\
\hline \multicolumn{13}{|l|}{ Education: } \\
\hline High School Grad or Less & 0.33 & 0.25 & 0.10 & 0.46 & 0.35 & 0.08 & 0.63 & 0.53 & 0.17 & 0.31 & 0.26 & 0.06 \\
\hline Some College & 0.21 & 0.23 & 0.29 & 0.24 & 0.27 & 0.39 & 0.20 & 0.25 & 0.35 & 0.23 & 0.24 & 0.15 \\
\hline Associates & 0.08 & 0.08 & 0.09 & 0.10 & 0.11 & 0.10 & 0.06 & 0.07 & 0.10 & 0.06 & 0.06 & 0.04 \\
\hline Bachelor's Degree & 0.25 & 0.29 & 0.29 & 0.14 & 0.18 & 0.26 & 0.09 & 0.12 & 0.27 & 0.31 & 0.32 & 0.46 \\
\hline Graduate Degree & 0.11 & 0.12 & 0.21 & 0.05 & 0.08 & 0.16 & 0.02 & 0.03 & 0.11 & 0.09 & 0.11 & 0.27 \\
\hline PhD/Professional Degree & 0.02 & 0.02 & 0.02 & 0.01 & 0.01 & 0.01 & 0.00 & 0.00 & 0.01 & 0.01 & 0.01 & 0.03 \\
\hline $\mathrm{N}$ & 5,839 & 4,826 & 1393 & 1,692 & 1,120 & 1264 & 2,725 & 1773 & 1547 & 1068 & 925 & 895 \\
\hline
\end{tabular}

Notes: * Internet users defined as those who use internet in their homes. Current Population Survey data are weighted estimates for those persons not currently married living in the Atlanta, Chicago, NY, or Los Angeles metro areas. Match.com data are weighted by sexuality and metropolitan area population size to match Current Population Survey. Weight for sexuality based on estimates of the size of the gay population in each metropolitan area obtained from the Williams Institute (Gates 2006). Standard Deviations for age are in parentheses. Other racial categories not shown. 


\begin{tabular}{|c|c|c|c|c|c|c|c|c|}
\hline & \multicolumn{4}{|l|}{ Gays } & \multicolumn{4}{|c|}{ Lesbians } \\
\hline & White & Asian & Black & Latino & White & Asian & Black & Latina \\
\hline \multicolumn{9}{|l|}{ Racial Preference } \\
\hline Prefers Own Racial Group Only & 17.65 & 2.43 & 9.53 & 4.41 & 21.08 & 6.13 & 12.41 & 11.42 \\
\hline Excludes Own Racial Group & 3.78 & 20.69 & 10.66 & 7.85 & 0.75 & 8.81 & 3.15 & 2.8 \\
\hline Prefers Own and Others or Any & 78.57 & 76.88 & 79.81 & 87.74 & 78.16 & 85.06 & 84.44 & 85.78 \\
\hline \multicolumn{9}{|l|}{ Dater Characteristics } \\
\hline Age (mean, standard deviation in parentheses) & $\begin{array}{c}37.41 \\
(12.83)\end{array}$ & $\begin{array}{c}31.82 \\
(9.36)\end{array}$ & $\begin{array}{r}34.48 \\
(11.18)\end{array}$ & $\begin{array}{r}30.37 \\
(9.82)\end{array}$ & $\begin{array}{r}32.88 \\
(11.19)\end{array}$ & $\begin{array}{c}31.77 \\
(8.99)\end{array}$ & $\begin{array}{c}30.98 \\
(9.89)\end{array}$ & $\begin{array}{r}30.08 \\
(10.08)\end{array}$ \\
\hline \multicolumn{9}{|l|}{ Education } \\
\hline High school grad or less & 7.99 & 7.99 & 10.82 & 19.65 & 13.10 & 2.68 & 15.79 & 20.61 \\
\hline Some college/Associate's degree & 25.67 & 25.67 & 35.06 & 35.26 & 31.93 & 23.75 & 48.42 & 42.62 \\
\hline College graduate & 35.34 & 35.34 & 24.39 & 17.73 & 26.20 & 34.87 & 12.28 & 10.54 \\
\hline Graduate degree & 21.18 & 21.18 & 18.42 & 13.29 & 16.87 & 22.99 & 7.02 & 6.56 \\
\hline Missing & 9.82 & 9.82 & 11.31 & 14.07 & 11.90 & 15.71 & 16.49 & 19.67 \\
\hline \multicolumn{9}{|l|}{ Body Type } \\
\hline Slender & 14.17 & 21.10 & 13.57 & 18.30 & 14.49 & 21.68 & 12.02 & 12.67 \\
\hline Athletic & 29.17 & 21.50 & 32.63 & 21.19 & 26.19 & 20.78 & 25.77 & 18.45 \\
\hline Average & 38.29 & 46.25 & 32.63 & 40.85 & 36.80 & 42.71 & 30.02 & 37.95 \\
\hline Plus Size & 16.83 & 8.11 & 19.39 & 17.34 & 19.84 & 9.19 & 29.67 & 25.66 \\
\hline Missing & 1.54 & 3.04 & 1.78 & 2.32 & 2.68 & 5.64 & 2.52 & 5.27 \\
\hline Height (mean inches) & 70.42 & 67.44 & 69.74 & 68.38 & 65.31 & 63.69 & 64.95 & 63.85 \\
\hline \multicolumn{9}{|l|}{ Political Views } \\
\hline Conservative & 4.76 & 1.83 & 4.36 & 3.83 & 1.05 & 3.07 & 3.50 & 3.03 \\
\hline Liberal & 34.59 & 36.92 & 29.56 & 30.08 & 27.56 & 35.63 & 13.46 & 20.28 \\
\hline Middle of the Road & 50.56 & 53.75 & 52.02 & 45.79 & 32.98 & 45.59 & 53.85 & 54.31 \\
\hline Other viewpoint & 5.46 & 4.46 & 6.79 & 7.09 & 6.78 & 9.96 & 11.54 & 8.16 \\
\hline Missing & 4.62 & 3.04 & 7.27 & 13.22 & 31.63 & 5.75 & 17.66 & 14.22 \\
\hline \multicolumn{9}{|l|}{ Region } \\
\hline Atlanta & 26.19 & 7.10 & 27.79 & 11.88 & 26.51 & 5.36 & 31.64 & 8.62 \\
\hline Chicago & 26.05 & 24.34 & 27.30 & 30.08 & 25.75 & 8.43 & 28.50 & 24.01 \\
\hline Los Angeles & 23.25 & 35.70 & 21.81 & 30.46 & 23.04 & 49.04 & 25.35 & 14.51 \\
\hline New York & 24.51 & 32.86 & 23.10 & 27.59 & 24.70 & 37.16 & 14.51 & 30.77 \\
\hline \multicolumn{9}{|l|}{ Religion } \\
\hline Not religious & 38.01 & 23.73 & 21.65 & 18.88 & 34.49 & 27.59 & 17.54 & 19.67 \\
\hline Judeo-Christian & 37.17 & 37.53 & 55.25 & 50.48 & 35.09 & 34.10 & 51.58 & 46.60 \\
\hline Other religion & 3.93 & 18.66 & 3.55 & 4.24 & 6.63 & 15.71 & 2.81 & 4.68 \\
\hline No answer & 20.90 & 20.08 & 19.55 & 26.40 & 23.80 & 22.61 & 28.07 & 29.04 \\
\hline Percent own racial group in dater's community & 44.75 & 12.92 & 32.35 & 35.00 & 52.07 & 15.50 & 33.55 & 37.56 \\
\hline \multicolumn{9}{|l|}{ Date Preferences } \\
\hline Religion & 20.48 & 14.81 & 26.98 & 15.61 & 26.70 & 20.31 & 27.72 & 20.37 \\
\hline Educational attainment & 43.06 & 40.77 & 41.36 & 37.76 & 44.88 & 45.98 & 39.82 & 31.85 \\
\hline Body type & 75.63 & 66.94 & 68.17 & 66.48 & 60.54 & 66.28 & 55.55 & 58.28 \\
\hline Height & 94.96 & 94.93 & 95.48 & 95.21 & 90.66 & 85.82 & 94.58 & 94.41 \\
\hline Overall choosiness $(\%)$ & 46.02 & 41.77 & 44.60 & 43.21 & 46.37 & 44.37 & 44.21 & 44.55 \\
\hline $\mathrm{N}$ & 713 & 493 & 619 & 519 & 664 & 261 & 570 & 427 \\
\hline
\end{tabular}


Supplemental Table 4: Homophily/Heterophily Preferences among Same-Sex Daters, Relative Risk Ratios from Multinomial Regressions

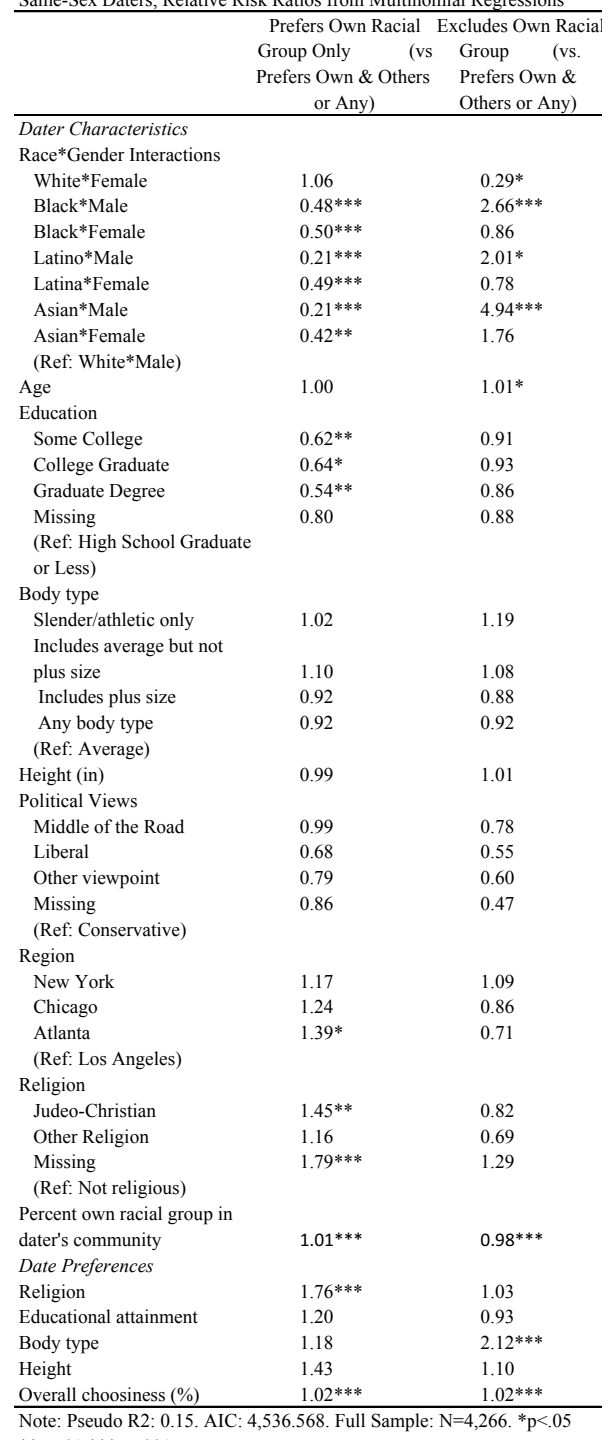

Note: Pseudo R2: 0.15. AIC: 4,536.568. Full Sample: $\mathrm{N}=4,266{ }^{*}{ }_{\mathrm{p}}<05$ $* * \mathrm{p}<.01 * * * \mathrm{p}<.001$. 
Supplemental Table 5: Homophily/Heterophily Preferences among

Lesbian Daters, Relative Risk Ratios from Multinomial Regressions

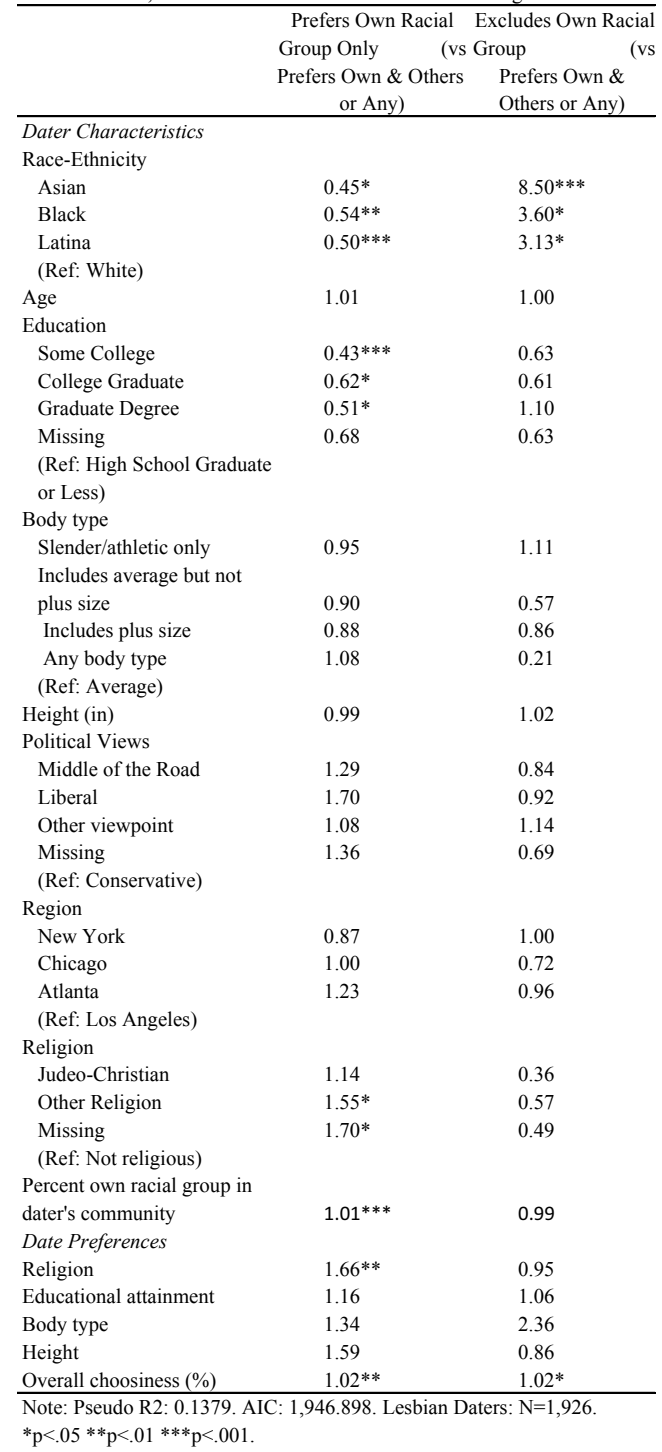


Supplemental Table 6Homophily/Heterophily Preferences among

Gay Male Daters, Relative Risk Ratios from Multinomial Regressions

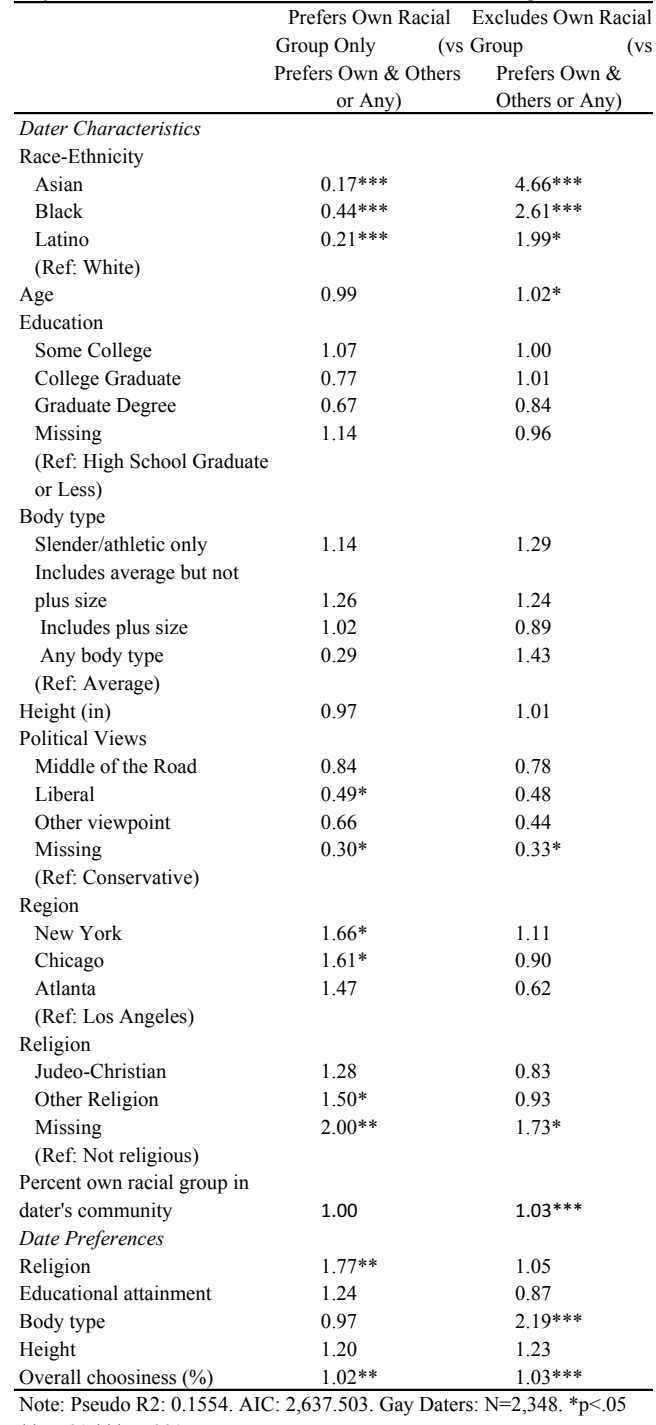

${ }^{* *} \mathrm{p}<.01 * * * \mathrm{p}<.001$. 
In this paper we use "lesbians" to refer to women-seeking-women and "gays" to refer to menseeking-men. Our decision was shaped by our finding that most same-sex daters referred to themselves with these terms in open-ended portions of their profiles. We use "gays" for men to provide parallelism with "lesbians" for women.

ii We use preferences to denote stated choices, but note that preferences are also shaped by opportunities, which may be limited, particularly for some racial groups.

iii We use the terms racial heterophily and racial self-exclusion interchangeably to refer to a preference for only dating racial groups other than one's own.

iv Each of these cities ranks in the top 10 in gay and lesbian population size (Gates 2006).

${ }^{v}$ In March of 2011, research assistants downloaded the first 200 profiles (within each race/gender/sexuality/region group) sorted by when daters joined the site. This sampling method allowed us to capture daters who are more likely to be active users of the platform and presently seeking partners. Match.com profiles are visible to anyone who creates an account. Because profiles were sorted based on daters' join date, researchers' own profiles did not affect profile searches. Only profiles with photos were used. We eliminated duplicate profiles, and have no reason to suspect fake profiles in our sample. In some cases, such as Asian lesbians in Atlanta, fewer than 200 profiles in that category were on the website.

${ }^{\text {vi }}$ We exclude those who identify with more than one racial-ethnic group since examining racial heterophily is difficult in these cases. For example, a person who identifies as White and Asian but prefers only to date Whites is not clearly racially homophilous or heterophilous.

vii While unfortunately Match.com does not ask users whether they want a long-term relationship, a search of dating website reviews indicates Match.com is a top dating website for serious-minded daters. Also, unlike other competitors, Match.com has always allowed gays and lesbians to seek members of the same sex for dates (Miller 2008); bloggers and review websites rank Match.com as a top dating website for gays and lesbians (Anon 2012; Ramsdale 2014). viii This may be because Match.com, at the time of data collection, did not allow individuals to search for both genders, and therefore bisexuals may be less likely to use the website or identify as such in their profile texts. Further, daters who are trans + have no other way to express their gender on Match.com given that male and female are the only available categories to select. ${ }^{i x}$ All daters entered their zip code, which was converted by Match.com to a publicly viewed town/city/municipality. Using the American Fact Finder website, we did a search for each municipality/town, or, if this was unsuccessful, an address search from that particular municipality/town, to obtain 2010 Census racial composition data. When using address search, the Census provides demographic characteristics based on several geographic areas, such as PUMA and School District. We gave preference to results from the smallest geographic areas. We found a wide range of racial compositions even within one metropolitan area.

x The most common preferences are to prefer to date one's own racial group along with other racial groups or to state openness to "any" racial group (see Supplemental Table 3). We collapsed these two categories because we found that effects of covariates on these outcomes were similar (in particular, we found no gender differences). Moreover, based on previous research (Hitsch et al. 2010), we doubt that those who do not state racial preferences (the default choice during profile creation) are truly racially open. We focus on racial homophily and racial self-exclusion because this is where we see gender differences in relation to the more common 
stated preference of openness (which are likely overestimated for social desirability reasons). Therefore, we believe preferences for other racial groups (heterophily) and for one's own racial group only (homophily) contribute the most to gender differences in partnership patterns.

${ }^{x i}$ While an alternative explanation might be that daters already expressed racial preferences in their profiles and do not need to explain further, our finding that Whites who prefer only minorities consistently discuss race suggests this is not the case.

xii Very few men stated a preference for feminine men or women state a preference for masculine women (less than 8 cases total) and few women self-described as masculine or butch $(\mathrm{N}=4)$ or as a tomboy $(\mathrm{N}=3)$. This is surprising given that research, particularly on lesbians, suggests that preferences exist along a spectrum of butch/femme. However, users could select photos for their dating profiles that convey a gendered presentation not described in their written entries. 